\title{
Morphometric characteristics of four important fish species from the Rwandan side of Lake Kivu
}

\author{
Antoine Nsabimana ${ }^{1, *}$, Wellars Banzi ${ }^{1}$, Valens Habimana ${ }^{1}$, Colores Uwamariya ${ }^{1}$, \\ Dieudonne Mutangana ${ }^{1}$
}

${ }^{1}$ University of Rwanda, College of Science and Technology, School of Science, PO Box 3900, Kigali, Rwanda

\begin{abstract}
Inland fisheries are important socio-economic resources for rural communities in Africa. In Rwanda, about two million people directly depend on capture fisheries from Lake Kivu. Sustainable fisheries management requires monitoring of population dynamics that help devise effective intervention strategies. However, the relevant data such as length-length and length-weight relationships do not exist for most of the key species in Lake Kivu. The present study generated morphometric and body weight data for Limnothrissa miodon $(\mathrm{n}=82)$, Lamprichthys tanganicanus $(\mathrm{n}=55)$, Haplochromis vittatus $(\mathrm{n}=51)$ and Haplochromis graueri $(\mathrm{n}=34)$ from Lake Kivu. Length-weight relationships $\left(\mathrm{W}=\mathrm{aL}^{\mathrm{b}}\right)$ were highly significant for all species $(\mathrm{p}<0.0001)$, high adjusted $\mathrm{R}^{2}=78$ to $98 \%$ of the variance in weight explained by total length. Negative allometric length-weight relationships were found with regression slope (b) values of 2.7 for Limnothrissa miodon, 2.8 for H. graueri, and 2.8 for L. tanganicanus, and positive $(\mathrm{b}=3.4)$ for Haplochromis vittatus. Length-length relationships were highly significant for all species $(\mathrm{p} \leq 0.0001)$, except for the relationship between total and caudal length for $L$. miodon, and total and caudal peduncle length for $L$. tanganicanus, both not significant at $\mathrm{p}>0.05$. The highest $\mathrm{R}^{2}$ was for the relationships between total and standard length for $H$. vittatus, and total and fork length for $L$. tanganicanus. No description of length-length relationships exists for these species in literature or in FishBase database. The data generated in the current study will be used to assess changes in fish populations over time.
\end{abstract}

Keywords: Haplochromis graueri; Haplochromis vittatus; Lamprychthys tanganicanus; Length-length relationship; Length-weight relationship; Limnothrissa miodon.

DOI: https://dx.doi.org/10.4314/ejst.v14i3.3

\section{INTRODUCTION}

Lake Kivu is one of the African Great Lakes found in the volcanic region between Rwanda and the Democratic Republic of Congo (DRC) in the Albertine Rift.

\footnotetext{
*Corresponding author: antoine.nsabimana@gmail.com (C)This is an Open Access article distributed under the terms of the Creative Commons Attribution License (http://creativecommons.org/licenses/CC BY4.0)
} 
Because of the methane deposits, Lake Kivu has poor fish fauna compared to other African Great lakes (Villanuevaa et al., 2008). Out of 28 fish species reported in the lake and its tributaries, 19 are cichlids (three Oreochromini, one Coptodonini and 15 endemic haplochromines), and nine non-cichlids (Dunz and Schliewen, 2013). Low fish diversity has been attributed to its geological history such as catastrophic events where the water of the lake was at high altitude from the mid-Miocene uplifting of the east-African region (Snoeks et al., 2012). The other lakes in this region, in particular Lake Tanganyika, Lake Malawi, Lake Victoria have much higher fish diversity compared to Lake Kivu (Snoeks et al., 2012).

Capture fisheries in Lake Kivu are a major source of protein and income for the riparian communities (Hanek et al., 1991). Limnothrissa miodon Boulenger 1906 (Clupeidae) was introduced in Lake Kivu in 1959 (Hauser et al., 1995) and has become a species of high commercial importance in Rwanda and the region, with stock ranging between 4,000 to 10,000 tons depending on the season (Lamboeuf, 1991; Mughanda and Mutamba, 1993; Guillard et al., 2012). Lamprichthys tanganicanus Boulenger 1898 (Procatopodidae, Procatopodinae) was also accidentally introduced into Lake Kivu and found in commercial catches of Limnothrissa miodon. Lamprichthys tanganicanus has invaded the whole lake, as it occurs in both, pelagic and littoral Zones, and it competes with L. miodon populations for food (Masilya et al., 2011). There is high diet overlap between these two species in the pelagic zone, but the overlap is lower in the littoral zone, likely due to the specific diet of $L$. miodon whereas L. tanganicanus has a catholic diet (Masilya et al., 2011).

Length-weight relationships (LWR) and length-length (LLR) are important characteristics used for fish stock assessment, predicting population dynamics, biomass estimates, comparative growth studies, and informing sustainable management of fisheries resources (Moutopoulos and Stergiou, 2002; Froese, 2006; McCallum 2008; Lteif et al., 2016; Elganainy et al., 2017). The maximum parameters of length are used indirectly to reflect fishing pressures and habitat suitability in a water body (Kohler et al., 1995; Mendes et al., 2005; Froese, 2006; McCallum, 2008). The LWR can change over time in seasons or days due to stomach filling, appetite and the gonad stage of the fish (Zaher et al., 2015). However, as for other poorly studied systems in Africa, there is a general lack of information on LLR and LWR for the fishes of Lake Kivu, including the commercially important species. The lack of this information is a major impediment to the effective management of important fish species in the lake, which are under severe fishing pressure and overexploitation. These parameters are only available for L. miodon, but they are based on an assessment of populations from Lake Kivu in mid- 1980's (Lamboeuf, 1989). However, 
observations from other populations where this species has been introduced, e.g., Lake Kariba and Cahora Bassa in southern Africa show that it has extreme morphological plasticity, while individuals from these introduced populations attain much smaller sizes than those in Lake Tanganyika and Kivu (Marshall, 1993). This highlights the need for generating these parameters for each population. The purpose of the present study was to generate morphometric data for L. miodon (for comparison with old data), L. tanganicanus, $H$. vittatus and $H$. graueri (for obtaining the new data) from Lake Kivu to provide basic information for fisheries science.

\section{MATERIALS AND METHODS}

A total of 223 fish specimens were sampled on the Protopine Northern (Rubavu, 81 specimens), Central (Karongi, 61 specimens) and Southern (Rusizi, 81 specimens) parts of Lake Kivu, on Rwandan side (Figure 1). Lake Kivu water samples were collected at Rusizi ( $\left.2^{\circ} 31.91^{\prime} \mathrm{S} 28^{\circ} 95.72^{\prime} \mathrm{E}\right)$; Rubavu $\left(1^{\circ} 41.154^{\prime} \mathrm{S}\right.$ $\left.29^{\circ} 8.292^{\prime} \mathrm{E}\right)$ and Karongi ( $\left.1^{\circ} 94.12^{\prime} \mathrm{S} 29^{\circ} 12.28^{\prime} \mathrm{E}\right)$. Among these, four species from 3 families, L. miodon (Clupeidae), L. tanganicanus (Procatopodidae), $H$. vittatus and $\mathrm{H}$. graueri (Cichlidae, Pseudocrenilabrinae) (Fricke et al., 2020) were collected in May (100 specimens, from all sites) and August 2018 (122 specimens, from Rubavu and Karongi sites only).

Democratic

Republic of

Congo

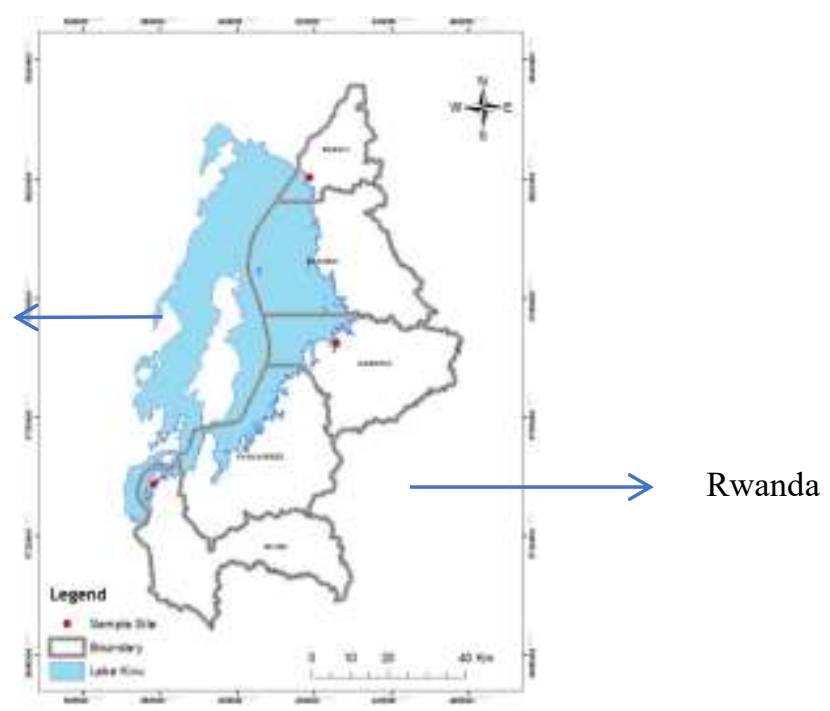

Figure 1. Map showing the sampled sites: From above, Site 1: Rubavu, Site 2: Karongi, Site 3: Rusizi 
The specimens were sampled using single line fishing gear and angling gill nets $(100 \times 2 \mathrm{~m}, 1.5-2 \mathrm{~mm}$ mesh size for $H$. graueri; $5-6 \mathrm{~mm}$ mesh size for L. miodon and L. tanganicanus), and using angling fishing rod for $H$. vittatus. The undamaged intact specimens were selected from the catch. Fishing time was $12 \mathrm{~h}$ overnight using petrol lamps for attraction for L. miodon and L. tanganicanus and horizontal placement of gill nets. The above described fishing methods were those used by local fishermen for the studied fish species. They were used in all three sites.

Specimens were identified according to Snoeks et al. (2012), while total length (TL), standard length (SL), caudal length (CL), head length (HL) and caudal peduncle length (CPL) were measured with a digital caliper to the nearest 0.01 $\mathrm{mm}$ (Figure 2) and body weight to the nearest $0.001 \mathrm{~g}$ with a digital balance for each specimen.

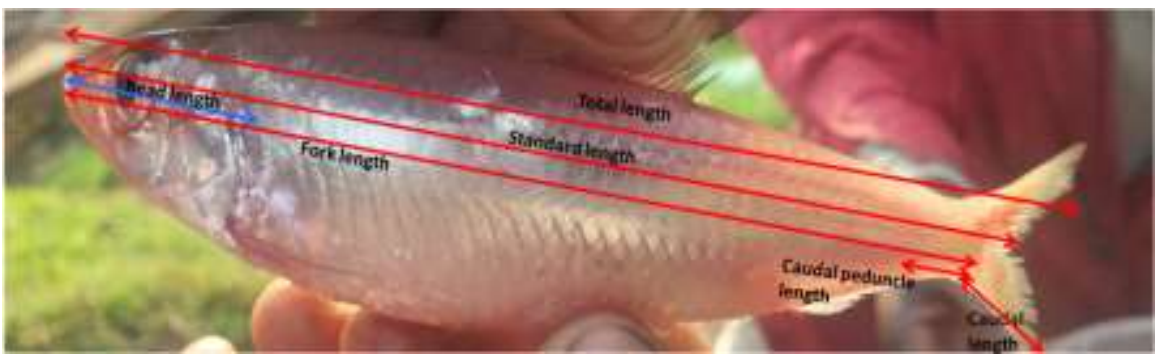

Figure 2. Different length measurements of fish specimens

All fish populations (considering one site - one population) were analyzed with analysis of variance, General Lineal Model for differences in length and weight for each species separately. The length and weight values were inspected for outliers visually by log-log plots (Froese, 2006). Linear regression was used for length-length relationship. An exponential regression equation was applied to describe weight with the total length for length-weight relationship where $\mathrm{W}$ is the weight $(\mathrm{g}), \mathrm{L}$ is the total length $(\mathrm{mm})$, a, the intercept, and $\mathrm{b}$, the slope of the logtransformed linear regression $\mathrm{W}=\mathrm{aL}^{\mathrm{b}}$ (Froese, 2006). The least square method was used for LLR estimation using the equation $\mathrm{TL}=\mathrm{a}+\mathrm{bSL}$ to estimate the degree of association between different fish length variables (Hossain et al., 2006), and to check the significance of $b$ value as being isometric, one-tailed Student's t-test with a confidence level of 95\% was used (Froese et al., 2011). 


\section{RESULTS AND DISCUSSION}

The specimens of $L$. miodon and $H$. vittatus were significantly smaller in Karongi as compared with those in Rusizi and Rubavu for both total length and weight (Table 1). In contrast, the specimens of $L$. tanganicanus were significantly bigger in Karongi than the other two sites. Weight and length of $H$. graueri did not significantly vary between any of the three sites $(\mathrm{p}>.05)$ (Table 1$)$.

$\mathrm{R}^{2}$ of LWR ranged from 0.78 for $L$. miodon to 0.97 for $H$. vittatus (Table 1 ). The value a ranged from 0.0000019 for $H$. vittatus to 0.000026 for $L$. miodon. Only $H$. vittatus had positive allometry with a 'b' value of 3.36. The other fish species had negative allometry of ' $b$ ' values of 2.71 for L. miodon, 2.83 for $H$. graueri and 2.84 for L. tanganicanus ( $<$ <.001 for all species, Table 1$)$.

The linear regressions of length-length relationships (LLR) were highly significant for all species $(\mathrm{p}<0.01)$, and $\mathrm{R}^{2}$ ranging from 0.46 to 0.99$)$, however, for some LLR, $\mathrm{R}^{2}$ values were very low: 0.11 for total and caudal length for $L$. miodon $(p<0.01)$, and 0.09 for total and caudal peduncle length for L. tanganicanus $(\mathrm{p}<0.05)$ (Table 2). For other species, $\mathrm{R}^{2}$ ranged from 0.46 for $H$. graueri $\mathrm{TL}-$ CPL relationship, and $0.99 \mathrm{H}$. vittatus for TL $-\mathrm{SL}$ relationship (Table 2).

In fisheries biology, length-weight relationship is useful in determining weight and biomass when only length measurements are available, as indications of the condition and to allow for comparisons of species growth between different regions (Koutrakis and Tsikliras, 2003). The current study showed that L. miodon and $H$. vittatus specimens from Karongi were significantly smaller in length and weight as compared to other sites. This could be an indication of over- fishing and more work is required on the breeding ground of these species to assess if there is insufficient restoration of fish stock at this site.

The biological parameters of fish from Lake Kivu were rarely studied and reported, particularly for Haplochromis spp. For all the four species studied, all b values were similar to those reported before, i.e., $b$ values ranged between 1.94 and 3.94 and $90 \%$ of LWR analyzed on 1773 species were found between 2.7-3.4 range (Froese, 2006). Our study established the value for intercept ' $a$ ' and regression coefficient ' $b$ ' for each of these species to keep length-weight relationships significant at a $95 \%$ confidence interval. While the length-weight relationships were reported for many fish species, the variations of the components of these relationships were rarely studied, at least, for the Kivu Lake fish species. Knowledge of these parameters would be a record of the biological variations, which belong to species characteristics and help to describe the growth pattern of a given species and its possible variations. 
Table 1. Means of total length, weight and length-weight relationship for fish species from Kivu.

\begin{tabular}{|c|c|c|c|c|c|c|c|c|c|}
\hline Species name & Site & $\mathbf{N}$ & $\begin{array}{l}\text { Total length } \\
(\mathrm{mm})\end{array}$ & $\begin{array}{l}\text { Weight } \\
\text { (g) }\end{array}$ & $\begin{array}{l}\text { (3 locations merged) } \\
\mathbf{W}=\mathbf{a} \mathbf{T L}^{\mathbf{b}}\end{array}$ & $95 \%$ CI for a & $\begin{array}{l}95 \% \mathrm{CI} \\
\text { for } \mathrm{b}\end{array}$ & $\begin{array}{l}\text { Adj } \\
\mathbf{R}^{2}\end{array}$ & P-value \\
\hline $\begin{array}{l}\text { L. miodon } \\
\text { (Isambaza) }^{1}\end{array}$ & $\begin{array}{l}\text { Karongi } \\
\text { Rubavu } \\
\text { Rusizi }\end{array}$ & $\begin{array}{l}26 \\
36 \\
20\end{array}$ & $\begin{array}{l}74.7(7.0) \mathrm{b} \\
79.8(9.7) \mathrm{b} \\
89.1(9.9) \mathrm{a}\end{array}$ & $\begin{array}{l}2.9(1.0) \mathrm{a} \\
4.1(1.8) \mathrm{b} \\
4.9(1.1) \mathrm{c}\end{array}$ & $\mathrm{W}=0.000026^{*} \mathrm{TL}^{2.71}$ & $\begin{array}{l}0.000006- \\
0.000103\end{array}$ & $2.4-3.0$ & 0.78 & 0.000 \\
\hline $\begin{array}{l}\text { L. tanganicanus } \\
\text { (Rwandarushya, } \\
\text { Pururu) }{ }^{1}\end{array}$ & $\begin{array}{l}\text { Karongi } \\
\text { Rubavu } \\
\text { Rusizi }\end{array}$ & $\begin{array}{l}11 \\
22 \\
22\end{array}$ & $\begin{array}{l}116.7(11.4) \mathrm{a} \\
92.0(15.6) \mathrm{b} \\
90.6(14.0) \mathrm{b}\end{array}$ & $\begin{array}{l}10.8(2.9) \mathrm{b} \\
6.6(3.9) \mathrm{a} \\
5.6(3.3) \mathrm{a}\end{array}$ & $\mathrm{W}=0.000015 * \mathrm{TL}^{2.84}$ & $\begin{array}{l}0.00007- \\
0.000029\end{array}$ & $2.7-3.0$ & 0.96 & 0.000 \\
\hline $\begin{array}{l}\text { H. vittatus } \\
\text { (Imyombo) }^{1}\end{array}$ & $\begin{array}{l}\text { Karongi } \\
\text { Rubavu } \\
\text { Rusizi }\end{array}$ & $\begin{array}{l}13 \\
13 \\
25\end{array}$ & $\begin{array}{l}103.0(15.1) \mathrm{b} \\
163.0(44.7) \mathrm{a} \\
142.9(37.5) \mathrm{a}\end{array}$ & $\begin{array}{l}11.4(7.0) \mathrm{a} \\
66.5(57.1) \mathrm{b} \\
41.6(30.0) \mathrm{b}\end{array}$ & $\mathrm{W}=0.000002 * \mathrm{TL}^{3.36}$ & $\begin{array}{l}0.000001- \\
0.000003\end{array}$ & $3.3-3.5$ & 0.97 & 0.000 \\
\hline $\begin{array}{l}\text { H.graueri } \\
\text { (Mupfumu) }^{1}\end{array}$ & $\begin{array}{l}\text { Karongi } \\
\text { Rubavu } \\
\text { Rusizi }\end{array}$ & $\begin{array}{l}10 \\
10 \\
14\end{array}$ & $\begin{array}{l}66.0(10.9) \mathrm{a} \\
69.4(9.8) \mathrm{a} \\
72.8(11.9) \mathrm{a}\end{array}$ & $\begin{array}{l}3.9(1.8) \mathrm{a} \\
4.5(1.9) \mathrm{a} \\
4.9(2.2) \mathrm{a}\end{array}$ & $\mathrm{W}=0.000025 * \mathrm{TL}^{2.83}$ & $\begin{array}{l}0.000008- \\
0.000079\end{array}$ & $2.6-3.1$ & 0.93 & 0.000 \\
\hline
\end{tabular}

1* Isambaza, Rwandarushya/Pururu, Imyombo, Mupfumu - are names of fish species in the local language; N: number of specimens; TL total length; $\mathrm{W}=$ weight; $\mathrm{CI}=$ confidence interval; $\mathrm{Adj}=$ Adjusted; $\mathrm{a}$ : regression parameter; $\mathrm{b}$ : slope of the regression; $\mathrm{R}^{2}$ : coefficient of determination; in the columns of Total length and weight, $a$ and $b$ values show the significant difference; $P$ values show the significance of the differences between means of a parameters between the three locations (Karongi, Rubavu and Rusizi) 
Table 2. Length-length relationships of total length (TL), standard length (SL), fork length (FL), Head Length (HL), Caudal Length (CL), and Caudal Peduncle Length (CPL) of four fish species, Lake Kivu.

\begin{tabular}{|c|c|c|c|c|}
\hline Species name & $\mathbf{N}$ & Equation: Length $1=\mathbf{a}+\mathbf{b} *$ Length $_{2}$ & Adjusted R $\mathbf{R}^{2}$ & $P$-value \\
\hline \multirow{7}{*}{$\begin{array}{l}\text { L. miodon (Isambaza) } \\
1\end{array}$} & \multirow[t]{7}{*}{82} & $\mathrm{TL}=2.56+1.17 \mathrm{SL}$ & 0.99 & 0.0000 \\
\hline & & $\mathrm{TL}=2.69+1.07 \mathrm{FL}$ & 0.97 & 0.0000 \\
\hline & & $\mathrm{TL}=7.03+4.30 \mathrm{HL}$ & 0.97 & 0.0000 \\
\hline & & $\mathrm{TL}=72.48+0.53 \mathrm{CL}$ & $0.11^{3}$ & 0.0016 \\
\hline & & $\mathrm{TL}=39.03+4.65 \mathrm{CPL}$ & 0.51 & 0.0000 \\
\hline & & $\mathrm{SL}=0.46+0.90 \mathrm{FL}$ & 0.97 & 0.0000 \\
\hline & & $\mathrm{FL}=-0.08+0.91 \mathrm{TL}$ & 0.97 & 0.0000 \\
\hline \multirow{7}{*}{$\begin{array}{l}\text { L. tanganicanus } \\
\text { (Rwandarushya, } \\
\text { Pururu) }\end{array}$} & \multirow[t]{7}{*}{55} & $\mathrm{TL}=1.40+1.19 \mathrm{SL}$ & 0.99 & 0.0000 \\
\hline & & $\mathrm{TL}=-3.58+1.09 \mathrm{FL}$ & 0.99 & 0.0000 \\
\hline & & $\mathrm{TL}=-3.87+5.96 \mathrm{HL}$ & 0.95 & 0.0000 \\
\hline & & $\mathrm{TL}=26.56+4.14 \mathrm{CL}$ & 0.71 & 0.0000 \\
\hline & & $\mathrm{TL}=72.75+1.60 \mathrm{CPL}$ & $0.09^{3}$ & 0.0165 \\
\hline & & $\mathrm{SL}=-3.66+0.91 \mathrm{FL}$ & 0.99 & 0.0000 \\
\hline & & $\mathrm{FL}=3.66+0.92 \mathrm{TL}$ & 0.99 & 0.0000 \\
\hline \multirow[t]{4}{*}{ H. vittatus (Imyombo) } & \multirow[t]{4}{*}{51} & $\mathrm{TL}=3.041183+1.190280 \mathrm{SL}$ & 0.99 & 0.0000 \\
\hline & & $\mathrm{TL}=18.84409+2.815968 \mathrm{HL}$ & 0.99 & 0.0000 \\
\hline & & $\mathrm{TL}=-14.0076+6.071934 \mathrm{CL}$ & 0.99 & 0.0000 \\
\hline & & $\mathrm{TL}=8.440437+7.036919 \mathrm{CPL}$ & 0.98 & 0.0000 \\
\hline \multirow[t]{4}{*}{ H. graueri (Mupfumu) } & \multirow[t]{4}{*}{34} & $\mathrm{TL}=6.06499875+1.1185055 \mathrm{SL}$ & 0.90 & 0.0000 \\
\hline & & $\mathrm{TL}=16.18537+2.807007 \mathrm{HL}$ & 0.90 & 0.0000 \\
\hline & & $\mathrm{TL}=13.15649+4.17048 \mathrm{CL}$ & 0.74 & 0.0000 \\
\hline & & $\mathrm{TL}=39.23739+3.531368 \mathrm{CPL}$ & 0.46 & 0.0000 \\
\hline
\end{tabular}

1: Isambaza, rwandarushya/pururu, imyombo, mupfumu - are names of fish species in the local language; N: number of specimens; ${ }^{3}$ b: Poor regression relationship; a: regression parameter; $b$ : slope of the regression, Adjusted $r^{2}$ : coefficient of determination; Length 1 and Length 2 are as specified below in regression equations.

When b-value is equal to 3.0, the growth is isometric, i.e., all fish dimensions increase equally (Froese et al., 2011). If ' $b$ ' value is less than 3.0, fish species increases in weight less than it can be predicted by an increase in length, thus it has negative allometric growth, or it becomes more elongated. When ' $b$ '-value is more than 3.0, species has positive allometric growth, or it increases in weight more than it can be predicted by an increase in length, fish becomes more rounded as it grows (Froese et al., 2011). For L. miodon the ' $b$ ' parameter falls in the range with those reported by Mulimbwa and Smrakihara (1994), b=3.27, a report on the L. miodon of the Lake Tanganyika. Other workers reported much lower b values, for example, Lamboeuf (1989) $(\mathrm{b}=2.27$ on Lake Kivu) and Froese and Pauly 
(2017) $(b=2.681$ for Zambian population of Limnothrissa and $b=2.863$ for Zimbabwean population of Limnothrissa in the FishBase). These differences might have developed from different ecological conditions existing in the lakes of this region, as well as differences in diets. For the rest of the species, no biological parameters either for the LWR or LLR were available in the literature and the different databases such as FishBase. Except $H$. graueri, total length and the standard-length were found highly related in the rest of the species, i.e., $r^{2}=0.99$, for L. miodon; $\mathrm{r}^{2}=0.99$ for L. tanganicanus; $\mathrm{r}^{2}=0.99$ for $H$. vittatus; and $\mathrm{r}^{2}=0.92$ for $H$. graueri.

Our study complements other research activities going on in Lake Kivu and focuses on fish feeding behavior and environmental biology (Masilya et al., 2020), species characterization for Cichlids (Munyandamutsa et al., 2020), and regional studies on fisheries management (Cowx and Ogutu-Owhayo, 2019; Kolding et al., 2019).

\section{CONCLUSION}

This study provides the baseline results for the LWR and LLR of the four species of fishes, namely, Limnothrissa miodon, Lamprichthys tanganicanus, Haplochromis vittatus and Haplochromis graueri from Lake Kivu. Further studies would focus on establishing current population dynamics, efficient management of fish populations through better understanding of feed habits and better monitoring of fish populations. Change in morphometric parameters would be monitored to further assess if the existing conservation measures and fishing ban are efficient to sustain fish populations in lake Kivu. These results will be used for fish population monitoring and stock estimation and relate the observed changes to fish population dynamics and catch control in the Lake.

\section{ACKNOWLEDGMENTS}

The authors are grateful to Mr Christophe Habiyambere for sampling at Rubavu site and parataxonomic activities, Baraka Cooperative and Mr Théophile Nyandwi for help in sampling at Karongi and Rusizi sites, respectively. This study was financially supported by Ordinary Research Grant under the University of Rwanda and Sweden Collaboration.

\section{REFERENCES}

Cowx, I.G and Ogutu-Owhayo, R. (2019). Towards sustainable fisheries and aquaculture management in the African Great Lakes. Fisheries Management and Ecology 26(5): 
397-405.

Dunz, A.R and Schliewen, U.K. (2013). Molecular phylogeny and revised classification of the Haplotilapiine cichlid fishes formerly referred to as "Tilapia". Molecular Phylogenetics and Evolution 68(1): 64-80.

Elganainy, A., Amin, A., Ali, A and Osman, H. (2017). Age and growth of two barracuda species Sphyraena chrysotaenia and S. flavicauda (Family: Sphyraenidae) from the Gulf of Suez. Egyptian Journal of Aquatic Research 43: 75-81.

Fricke, R., Eschmeyer, W. N and R. van der Laan (eds.) 2020. Eschmeyer's catalog of fishes: General, Species, References. (http://researcharchive.calacademy.org/research/ichtyology/catalog/ fishcatmain.asp), (accessed 25 March 2020).

Froese, B.R. (2006). Cube law, condition factor and weight - length relationships : history, meta-analysis and recommendations. Journal of Applied Ichthyology 22: 241-253.

Froese, R and Pauly, D. (eds.) (2017). FishBase, World wide web electronic publication. http://www. fishbase.org (accessed March 25, 2020).

Froese, R., Sikliras, A and Stergious, K. (2011). Editorial Note on Weight - Length Relations of Fishes. Journal of Applied Ichthyology 41: 261-263.

Guillard, J., Darchambeau, F., Masilya, P and Descy, J. (2012). Is the fishery of the introduced Tanganyika sardine (Limnothrissa miodon) in Lake Kivu (East Africa) sustainable? Journal of Great Lakes Research 38(3): 524-533.

Hanek, G., Kees, L and Farhani, B. (1991). Socio Economic Investigations of Lake Kivu Fisheries. http://www.agris.fao.org, (accessed March 25, 2020).

Hauser, L., Carvalho, G.R and Pitcher, T.J. (1995). Morphological and genetic differentiation of the African clupeid Limnothrissa miodon 34 years after its introduction to Lake Kivu. Journal of Fish Biology 47: 127-144. http://doi.org/10.1111/j/1095-8649.tb06049.x

Hossain, B.M.Y., Ahmed, Z.F., Leunda, P.M., Jasmine, S., Oscoz, J., Miranda, R and Ohtomi, J. (2006). Condition, length-weight and length-length relationships of the Asian striped catfish Mystus vittatus (Bloch 1794) (Siluriformes: Bagridae) in the Mathabhanga River, Southwestern Bangladesh. Journal of Applied Ichthyology 22(4): 304-307.

Kohler, N.E., Casey, J.G and Turner, P.A. (1995). Length-weight relationships for 13 species of sharks from the western North Atlantic. Fish Bulletin 93(2): 412-418.

Kolding, J., van Zwieten, P.A., Marttin, F., Funge-Smith, S and Poulain, F. (2019). Freshwater small pelagic fish and fisheries in the main African great lakes and reservoirs in relation to food security and nutrition.FAO Fisheries and Aquaculture Technical Paper, 642, Rome FAO, 124p.

Koutrakis, E.T and Tsikliras, A.C. (2003). Length-weight relationships of fishes from three northern Aegean estuarine systems (Greece). Journal of Applied Ichthyology 19: 258 260.

Lamboeuf, M. (1991). Abondance et répartition du Limnothrissa miodon du lac Kivu, résultats des prospections acoustiques d'avril 1989 à juin 1991 . RWA/87/012/DOC/TR/46, Rwanda, Gisenyi. 11 p.

Lamboeuf, M. (1989). Estimation de l'abondance du stock d'Isambaza (Limnothrissa miodon), résultats de la prospection acoustique de septembre 1989. RWA/87/012/DOC/TR/20, Gisenyi. 13 p.

Lteif, M., Mouawad, R., Jemaa, S., Khalaf, G., Lenfant, P and Verdoit-jarraya, M. (2016). 
The length-weight relationships of three sharks and five batoids in the Lebanese marine waters, eastern Mediterranean. Egyptian Journal of Aquatic Research 42: 475-477.

Marshall, B.E. (1993). Biology of the African clupeid Limnothrissa miodon with reference to its small size in artificial lakes. Reviews in Fish Biology and Fisheries 3(1): 17-38.

Masilya, M.P, Darchambeau, F and Isumbisho, M. (2011). Diet overlap between the newly introduced Lamprichthys tanganicanus and the Tanganyika sardine in Lake Kivu, Eastern Africa. Hydrobiologia 675: 75-86.

Masilya, M.P., Muvundja, F.A., Isumbisho, M., Hyangya, L., Kisekelwa, T and Kaningini, M.B. (2020). Food and feeding habits of Raïamas moorei Boulenger 1900, Enteromius pellegrini (Poll, 1939), and Enteromius kerstenii (Peters, 1868), three cyprinid species of Lake Kivu (East Africa). Environmental Biology of Fishes 103: 635-645.

McCallum, H. (2008). Population Parameters: Estimation for Ecological Models. In: Lawton, G.H., Likens, G.E. (Eds) Methods in Ecology, vol. 3, John Wiley and Sons, Blackwell Science, London.

Mendes, B.B., Fonseca, P and Campos, A. (2005). Weight - length relationships for 46 fish species of the Portuguese west coast. Journal of Applied Ichthyology 20: 355-361.

Moutopoulos, D.K and Stergiou, K.I. (2002). Length-weight and length-length relationships of fish species from the Aegean Length-weight and length - length relationships of fish species from the Aegean Sea (Greece ). Journal of Applied Ichthyology 18: 200-203.

Mughanda, M and Mutamba, A. (1993). Thirteen years of exploitation of Limnothrissa miodon BLGR in Lake Kivu (Rwanda and Zaire). In: Marshall B.E and Mubamba R. (Eds.): Papers presented at the symposium on biology, stock assessment and exploitation of small pelagic fish species in the African great lakes region. Bujumbura, Burundi, 25 to 28 November 1992. FAO, CIFA Occasional paper 1993, N 19, 270. 16.

Mulimbwa, N and Smrakihara, K. (1994). Growth, recruitment and reproduction of sardines. Tropics 4: 57-67.

Munyandamutsa, P., Jere, W.L., Kassam, D and Mtethiwa, A. (2020). Species specificity and sexual dimorphism in tooth shape among the three sympatric haplochromine species in Lake Kivu cichlids. Ecology and Evolution 10: 5694-5711.

Snoeks, J., Kaningini, B., Masilya, P., Nyinawamwiza, L and Guillard, J. (2012). Fishes in Lake Kivu; Diversity and fisheries. In: Limnology and Biogeochemistry of a Tropical Great Lake. pp.127-152 (Descy, J.P., Darchambeau, F., Schmid M. (eds.). Aquatic Ecology Series 5, DOI 10.1007/978-94-007-4243-7_8. Springer, Dordrecht.

Villanuevaa, S., Isumbisho, M., Kaningini, B and Michā, J.C. (2008). Modeling trophic interactions in Lake Kivu: What roles do exotics play? Ecological Modeling 212: 422 438.

Zaher, M., Rahman, B.M.S., Rahman, A and Ashraful, M. (2015). Length-weight relationship and GSI of hilsa, Tenualosa ilisha (Hamilton, 1822) fishes in Meghna river, Bangladesh. International Journal of Natural and Social Sciences 2: 82-88. 